\title{
ВОДЕНИЧКА ТЕРМИНОЛОГИЈА И ВОДЕНИЧАРСКА ЛЕКСИКА У СРПСКОМ ГОВОРУ КАРАШЕВА
}

\begin{abstract}
Овај рад јесте један у низу наших радова насталих у оквиру личног мини пројекта аутора чији је циљ испитивање оних области сеоског живота Карашевака, тачније оних занимања и заната који су у условима све убрзаније глобализације пред издисајем или су већ нестали ${ }^{3}$. Након неколико уводних напомена о теренској анкети и казивачима, о воденицама и воденичарству у Карашеву, истиче се да је основни циљ рада да се прибележи и на тај начин конзервише воденичка терминологија и лексика воденичарског заната који је у Карашеву изумро. Садржај рада састоји се у приказу прикупљене грађе и њеној анализи која има за циљ да укаже на порекло термина и лексема из овог домена људске активности и да установи у којој мери су други језици утицали на овај сегмент лексике.
\end{abstract}

Кључне речи: Карашево, воденице, воденичарство, воденичка терминологија, воденичарска лексика.

1. Вода је, поред земље, ваздуха и ватре, једно од основних природних елемената и један од предуслова за живот на нашој планети (Милорадовић, 2013: 11). У директној вези са водом јесте воденичарство, једно од врло старих занимања које је, све до недавно, заузимало веома важно место у животу сеоских заједница и представљало значајан део привредне снаге старог, традиционалног села, а млинови и воденице представљају основу воденичарства. На жалост, већина старих, традиционалних сеоских воденица и млинова скоро да више и нема, а оне које су до данас опстале

\footnotetext{
11mradan54@yahoo.com, mihai.radan@e-uvt.ro ; miliana83@yahoo.com, miliana.uscatu@e-uvt.ro

${ }^{2}$ Рад је настао у оквиру пројекта Истраживане културе и историје Срба у Румунији Центра за научна истраживања културе Срба у Румунији.

${ }^{3}$ До сада штампани су радови о коларској, ковачкој, кожухарској и пастирској терминологији (види: Радан, 2017: 329-344; Радан, Ускату, 2016: 55-67; Радан, Ускату, 2018: 41-53; Радан, Ускату, 2019: 615-626).
} 
запуштене су и, ако се нешто не буде хитно предузело, оне ће сасвим пропасти и нестати. Узрок оваквог катастрофалног стања воденичарства лежи у томе што се ово занимање међу првима нашло на удару убрзаног процеса индустријализације савременог света (Финдрик, 1983: 95; Тешић, 1988б: 287) и, у последњим деценијама, процеса глобализације. Овакво садашње стање воденичарства свуда у цивилизованом савременом свету (в., нпр. Муњић, 2017), укључујући ту и карашевску област, потакло нас је да спроведемо анкету о воденицама и воденичарском занимању у карашевским селима. Истраживање има у виду постизање неколико главних циљева, наиме, да се: 1) у последњи час попише воденичарска терминологија и лексика везана за ово занимање; 2) опишу елементи погонског дела карашевске воденице и начин функционисања целокупног воденичног постројења (млинског механизма); 3 ) открију одредбе старог воденичарског обичајног права (власнички односи) у Карашевака; 4) значај воденичарства у свакодневном сеоском животу. Пошто је дужина радова који се штампају у овом часопису ограничена, првенствени нам је циљ да за сада дамо преглед и порекло забележене воденичке терминологије и лексике везане за овај домен, те да у грубим цртама опишемо стање воденичарског заната и воденица у последњих седамдесетак и више година, са напоменом да остале циљеве намеравамо остварити објављивањем монографске студије о карашевским воденицама у блиској будућности.

2. Хидрографска мрежа Баната је богата. Нера, Брзава, Поганиш, Тамиш (извиру из планине Семеник), Караш (извире из Анинскких планина), Бистра, Черна спадају у веће реке које протичу јужним брдско-планинским делом Баната и свака од њих има бројне притоке, а у равничарском Банату (Тамишка жупанија) највеће су реке Мориш и Бегеј. Такав богат хидрографски басен погодовао је развоју воденичарства у Банату још у средњем веку, а можда и раније. Први сачувани документ који говори о постојању двеју воденица на банатском тлу (на рекама Тамишу и Брзави) налазимо у једном канцеларијском запису из XIII века (1256. године), а први запис о постојању једне воденице на Карашу потиче из XIV века (1363) (Țeicu, 2012: 374-377). Постојање многобројих млинова и воденица потврђују и разни новији статистички подаци од XIX века наовамо, од којих наводимо неколико: 1828. пописано је 380 воденица у Карашкој жупанији, а у Тамишкој - 367, 1957. у (румунском) Банату било је 74 воденице са вертикалним и 500 са хоризонталним колом, а у првој деценији XXI века, према најновијим статистикама, „сачувано је мало преко 100“ воденица у Банату (T,eicu, 2012: 381).

3. Као што је познато, у јужном брдско-планинском делу данашњег 
румунског Баната, у једној котлини у горњем току реке Караша са подножја највеће банатске планине Семеник, Караш-Северинска жупанија, смештено је седам карашевских насеља: Кара́шево (Caráşova), Jáбалч'e (Iabálcea), Не́рмиђ' (Nérmed) ${ }^{4}$, Клоко́тич' (Clócotici), Лу́пак (Lúpac), Ра́вник (Ráfnic) и Во́дник (Vódnic) ${ }^{5}$.

3.1. Кроз Карашево, највеће међу карашевским насељима у којем живи скоро половина Карашевака, протиче река Караш. Захваљујући тој чињеници у Карашеву су одувек постојали повољни услови за развој воденичарства, што потврђује знатан број воденица у овом насељу. Кроз сва остала карашевска насеља, осим Јабалча, протичу мали поточићи на којима нису постојали неопходни услови за градњу воденица. Једино кроз Јабалче, најмање карашевско насеље, не протиче никакав поточић и оно је све до недавно, често у летњим месецима, поготово у сушним годинама, због карстног тла на којем се налази, кубурило са пијаћом водом. Дакле, осим Карашева, ни у једном другом карашевском насељу нису постојале воденице.

3.2. Према информацијама које смо добили од ниженаведених и од других, случајних казивача, претежно из Карашева и Јабалча, али и из других карашевских насеља (Клокотич, Нермић, Равник) (в. Списак казивача у Анексима), у старије време (до седамдесетих година XX века), Карашевци из осталих шест насеља доносили су џакове кукуруза на кочијама, волујским колима и магарцима на млевење у воденицама у Карашеву. Мештани из Карашева, најчешће жене, доносили су велике џакове пуне кукурузних зрна и потом из млина односили џакове брашна на глави (в. и код Sebestyén, 1908: 59). Карашевци из нешто удаљенијих насеља од Карашева, из општине Лупак - Лупак, Равник, Водник, и Клокотич, млели су кукуруз понекад и у оближњим мање удаљеним румунским насељима, као што су Жити́н (рум. Jitin), Дукња́ч'a (рум. Docnecea), Ма́ли Тиква́њ (рум. Ticvaniul Mic) ${ }^{6}$.

3.3. Почев од седамдесетих година прошлога века, знатан број домаћинстава из свих седам насеља почео је израђивати мале воденице на електромоторни погон ${ }^{7}$ (сл. 5) или куповати мале млинове чекићаре у трговинским радњама. Тај период означиоје почетакнестанка традиционалне карашевске воденице, а оне које су се до тада одржале - већ у последњој деценији прошлога века сасвим ће изаћи из употребе (в. сл. 1, 2, 3 и 4).

\footnotetext{
${ }^{4}$ У заградама су дати званични румунски називи карашевских насеља.

${ }^{5}$ Детаље о географском положају ових насеља и становништву види код Радан, 2015: 21-23.

${ }^{6}$ Према казивањима Мúље Бо́шке из Равника и Марја́на Лукач'е́ле из Клокотича.

${ }^{7}$ Имају исти механизам и исте компоненте (укључујући два млинска камена - горњи и доњи, изузев, наравно, точка са перајима) као воденице поточаре.
} 
4. Анкету у Карашеву за прикупљање воденичарске терминологије и, у опште, лексике из овог домена, спровели смо у два наврата - 9. августа 2020. и 5. марта 2021. године. За прву анкету (2020) грађа је прикупљена на основу упитника из рада Милете Букумирића (Букумирић, 2002: 159$174)^{8}$ од четири казивачице, све из Карашева ${ }^{9}$ (в. сл. 6), а за другу анкету користили смо претежно Тешићев (Тешић, 1998), а када је било неопходно и Букумирићев ${ }^{10}$ упутник. За ову другу анкету за казивача изабрали смо Марјана /Петра/ Калину (в. сл. 7). Користимо прилику да се најискреније, топло захвалимо свим нашим љубазним и предусретљивим казивачима, који су током анкета исказали велику стрпљивост и уложили видне напоре да одговоре на што већи број питања и подсете се што већег броја назива воденичних делова.

Упркос чињеници да смо имали чак пет казивача, известан број питања из упитника остао је без одговора, а узрок томе јесте чињеница што су прошле најмање четири деценије од када воденице ефективно више не раде, па су казивачи поједине називе воденичних делова заборавили или их се у моменту анкете нису могли сетити. Услед тога намеравамо спровести и трећу анкету са другим казивачима ради попуњавања што већег броја питања из упитника, па да потом целокупну добијену грађу детаљно прикажемо и анализирамо у планираној будућој монографској студији.

4.1. Све воденице у Карашеву биле су са хоризонталним колом (точком). Тачан опис архитектуре можда највеће воденице у Карашеву (Ве́лика водени́ца) дао је почетком прошлога века мађарски етнолог Кароји Шебешћин (Sebestyén, 1908: 50-59), што се може закључити упоређивањем са архитектуром исте воденице која се до данас одржала (премда у веома лошем стању) (в. сл. 1 и 2). Иначе, последње три воденице које данас још постоје у Карашеву постојале су и те 1908. године, што значи да су оне, судећи према изгледу данашње наведене воденице, као грађевине остале у суштини нетакнуте. У основи то су правоугаоне грађевине, неке у облику издуженог четвороугаоника (в. сл. 1-4), постављене на надзиданим каменим (зи́m /zid*/11) темељима (фундаме́нm /fundament*/), саграђене од хоризонтално слаганих, на крајевима ућертаних брвана /obad*/, /brona*/ ( требало би бр̆вно, највероватније Шебешћин није добро чуо лексему или је погрешно забележио њен облик) /, без тавана, са једним улазом (вра́ma /

\footnotetext{
${ }^{8}$ Понекад, ређе, онда када је било потребно појаснити неки термин који је код казивача изазивао недоумицу, користили смо и Тешићев упитник (Тешић, 1998a: 529-534).

${ }^{9}$ Види, на крају рада, списак казивача са њиховим основним подацима.

${ }^{10}$ Види горњу фусноту (6).

${ }^{11}$ Називи написани латиничким писмом и означени звездицом унутар косих заграда $(/ * /)$ забележени су у раду мађарског истраживача (Sebestyén, 1908).
} 
vrata*/) и двоводним (по́кров у две́ во́де - сл. 3) или четвороводним кровом (по́кров у чети́ри во́де - сл. 1, 2) /pokrov*/. Неке од њих биле су једноделне, и имале су у унутрашњости само једну просторију у којој се обављало млевење кукуруза (мање жита или овса), док су друге биле дводелне и имале су још једну малу собу (со́биц̧а) која је служила за одмор воденичара. Било је и воденица које су имале један о́блук (,прозор), обично мали прозорчић (облу́' $\left.и \hbar^{\prime}\right)$, неке и два, чак и три прозорчића. Једна од њих, поменута Ве́лика водени́ца (сл. 1, 2) (можда и још нека у прошлости), има кров нешто дужи од саме зграде образујући тзв. трна́u /trnac*/ „трем“, који штити врата и бр̆вна једног од чети зида млина од кише или снега. У недавној прошлости биле су покривене ши́ндром, а последњих деценија пле́кам (лимом) или цийлом (црепом). У једном углу имале су (понеке) мало огњи́ume lognjište */12 бес ко́ша (,без димњака“), а брвна у ћошку око огњишта била су обложена гъило́м (,глином“) и тај део се зове ками́на /kamina*/ (в. Sebestyén, 1908: 54; нацрт 8). Извесне мање промене у односу на оно што је у том раду забележено пре сто и више година тичу се самог воденичног механизма млевења и уређаја за пренос снаге, што се може видети упоређујући нацрт млина из 1908. (нацрт 8) са нашим нацртом који илуструје механизам с почетка XXI века (нацрт 9).

4.2. К. Шебешћин је у свом чланку о карашевској воденици, штампаном 1908. године, навео податак даје у Карашеву тада било 14 воденица (Sebestyén, 1908: 50). Наше казавачице се присећају да је у њиховој младости било 10 воденица у Карашеву. На самом излазу из кањона и улазу Караша у село, на месту Три́ водени́ще и Гургу́ymегк, биле су, као што и први микротопоним указује, три воденице, наиме, на десној обали Караша налазиле су се $\underline{\text { Béлика }}$ водени́иа (једина од трију која још и данас постоји на локацији Три́ водени́це), Ка́меница (која се срушила негде средином прошлога века) и трећа, чије име ниједан од казивача више није знао, налазила се $\left(*{ }_{*}^{*}\right)^{13}$ прико ре̣́ке, на левој обали, која се највероватније урушила почетком XX века. На рукавцу који се на том месту издваја од Караша, само стотинак метара ниже налазила се Ђ'úнкулова водени́ца, а још ниже, опет на неколико стотина метара, налази се и данас А́рсулова водени́ча (на четрдесетак метара од центра насеља) (сл. 4). Наведених пет воденица налазе (налазиле су) се у горњем делу насеља (четврти) званом Поткр́ше. Неколико стотина метара ниже, у централном делу насеља, ниже од главног пута званог Ве́лики Сока́к (или Ве́лики пу́m),

\footnotetext{
${ }^{12}$ Највероватније ватра није служила за кување (спремање хране), већ само за загревање (Sebestyén, 1908: 54).

${ }^{13}$ Знак * испред одговора означава информацију добијену од Марјана Петра Калине, а знаком * испред одговора маркирали смо информацију добијену од казивачица у току прве анкете (в. Списак главних казивача). Одговори немаркирани неким од ова два знака потичу од четири главне казивачице са напоменом да се њихови одговори у суштини поклапају са одговором петог главног казивача (Калина).
} 
налази се Ге́рина водени́ua (сл. 3). У доњем делу насеља, у четврти Ку́рjач'uųa, налазила се Ка́рлина водени́ua, а ниже ње, на излазу Караша из Карашева, у Паланку́ци, била је још једна воденица чије име информаторке нису знале да нам саопште, једино је пети информатор знао тачније одредити место где се налазила (* ) кот Пи́рче за гради́ном. Од друге информаторке ${ }^{14}$ сазнали смо да је у том доњем делу насеља, било седам воденица: већ наведена Ка́рлина,

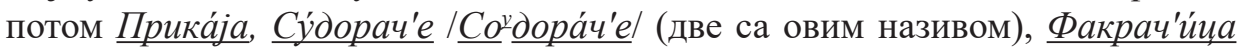
и Степюа́ч'a. Према казивању Петра Калине, једна воденица налазила се негде близу циганске четврти (део насеља у којем су груписане ромске куће).

4.3. Осим наведених воденица којих је било или их још има у самом селу (укупно три), информатори су нам саопштили да су од својих старих чули да су постојале још две воденице ван села. Прва, удаљена око 5 км узводно, налазила се у малој ували званој Про́лаз. У тој ували било је петнаестак салаша и до ње се могло стићи само пешке, путањом исклесаном у стени изнад Караша званом Pajumáj ${ }^{15}$ или, у најбољем случају, магарцем једним околним путићем. На тим салашима су све до прве половине прошлог века, преко целе године стално обитавали најмање један или више чланова породица који су ту имали салаше, узгајали стоку, живину, сејали кукуруз, кромпир, поврће, садили воћке (постојао је и казан за печење ракије), па им је на том изузетно тешко приступачном месту био неопходан млин. Друга воденица се налазила низводно, недалеко од насеља, на месту званом Кот Фи́риза ${ }^{16}$.

Такође ван села, узводно око 2,5-3 км, између места Пе́ћ'ка Љи́љач'ка (Пећина Слепих мишева) и Си́ғак на Карашу, на месту званом Ваља́вица, постојало је некада постројење за ваљање сукна (*: my се ваља́ле хаљи́не) ${ }^{17}$.

4.4. Скоро од самог извора све до суседног насеља Грлишта (рум. Gârliște), Караш протиче кроз карашевски атар, тако да се са леве и са десне стране реке налазе шуме, пашњаци, воћњаци и ливаде које су некада биле, а и данас су добрим делом у власништву општине и/или становника

\footnotetext{
${ }^{14}$ Називе ових пет воденица у доњем делу насеља (Ки́рjач'uца и Паланку́иа) саопштила нам је информаторка Марија Радан (Кумесарка).

${ }^{15}$ Сложен топоним немачке провенијенције настао од лексема Reich „царство“ и Steg „путања, стаза“, што би у преводу значило „Царска путања“. Највероватније је ова стаза пројектована и изграђена по налогу аустријске администрације у Банату или од аустро-француског трговачког друштва StEG (Staats Eisenbahn Gesellschaft, комплетни назив - Kaiserliche und königliche privilegierte österreichische Staats Eisenbahn Gesellschaft), основаног у Бечу 1834. године, које је изградило прве железничке пруге у Банату и Румунији и имало све до Првог светског рата у свом власништву велике површине планинског Баната (http://enciclopediaromaniei.ro/ wiki/StEG).

${ }^{16}$ На истом месту налазила се и једна пилана.

${ }^{17}$ Сам топоним указује да се ту налазило такво постројење (в. значење лексема „ваљарица, ваљаоница“) са погоном на воду.
} 
Карашева и Јабалча. На том подручју било је безброј салаша на којима су живели током целе године чланови породица (понекад и целе породице) из наведених двају насеља. Недалеко од извора Караша, на удаљености од око

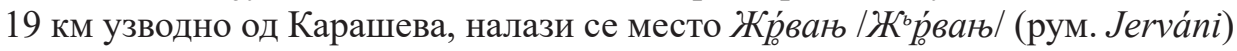
(в. Sencu, 1983: 32). Семантика овог топонима упућује на то да је на том месту вероватно некада постојао било неки жрвањ, било мала воденица поточара која је опслуживала становнике тих карашевских салаша.

5. Дајемо у наставку одговоре (курзивом) на питања из упитника М. Букумирића $^{18}$ (Букумирић, 2002) и М. Тешића (Тешић, 1998а), као и из упитника који смо ми урадили.

1. КСЗ (како се зове/зову) просторија у којој се мељу житарице? $\rightarrow$ водени́ща /vodenica*/.

2. КСЗ мала воденица? $\rightarrow$ ма́ла водени́йа, водени́ч'ка ${ }^{19}$.

3. КСК (како се каже) за миша који живи у воденици? $\rightarrow$ водени́ч'ни миш.

4. КСК кад се подигне ниво воде толико да поплави воденично коло да не може да се окреће? [^] $\rightarrow$ - [не ме́ље, не ра́dи, не ме́љемо, не пи́шћ'амо кад је толи́ка во́да].

5. За спречавање воде да тече јазом користи се глагол ,јазити“ [смо јази́ли].

6. Канал којим се спроводи вода до воденице назива се jác ${ }^{3}$ или jару́za ljaruga*/ [све и́сто је, и́деш да ч'и́стиш ја́с или јару́гу, да ја́зимо].

7. Место где се скреће вода да тече јазом: - .

8. а) Канал кроз који се вода слива у воденичко коло назива се жљьén /žljeb*/ (уп. жље̂́ $\rightarrow$ Букумирић, 2002: 160);

б) Корито кроз које се вода слива у воденичко коло назива се: [*]

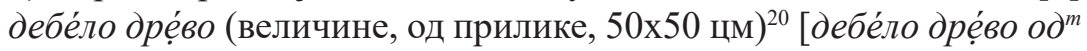
гоуру́на или бу́ка иско́пано].

9. За сужени отвор на доњем крају жлеба од казивачица нисмо добили одговор - [жље̣́n је по у́зак /од јаза/ ?], али у току друге анкете сазнали смо [**] да горњи крај жљеба није шири од доњег.

10. Преграда на јарузи пре жлеба помоћу које се вода зауставља или пушта да тече на воденично коло зове се cmáвило /stavilo*/. Током друге анкете казивач нам је саопштио да постоје две преграде (*: двá cmáвила), а друга преграда се подизала онда када воденица није радила, те се вода из јаруге пуштала у реку (в. Нацрт 9 у Анексима).

\footnotetext{
${ }^{18}$ Нека од дотичних питања су реформулисана, адаптирана карашевском говору.

${ }^{19}$ Водени́ч'ка јесте и назив за једну омиљену друштвену игру (в. и уп. „водѐница“ - РСХКНЈ, књ. II, стр.729).

${ }^{20}$ Данас се више не користи, место њега данас је цементни канал.
} 
11. Точак испод воденице на који пада и покреће га млаз воде зове се ка́рика /peračna [?] karika*/21.

12. Пераје (некада издубљене дашчице, данас гвоздене) на воденичком колу називају се пе́pa /pera*/.

13. Гвоздени круг који учвршћује пера на колу/точку назива се [*] о́бруч'[о́бруч'от желе́за].

14. Доњи део кола, онај у који су уграђена пера зове се [*] глави́на; [*] -.

15. Метално лежиште причвршћено на попречној греди (ра́сови) у које улази врх воденичког вретена зове се [*] бро́нза [nápч'e желе́зно, оие́л што се не ује́da] /brónca*/.

16. Ни један од казивача није знао назив за шиљати комад гвожђа усађен у средину главине који кружи у бронзи: - /сер $* /$.

17. Само један казивач је знао назив за попречну греду на којој је фиксиран воденични точак [* ра́сова; * - ] /rasova*/, која једним својим крајем лежи у једном отвору каменог зида (темеља), а други јој је крај причвршћен железном узенгијом/званом sloga*/ за другу греду /звану: medvęica*/, која је „обично за педаљ-два изнад дна јаруге испод млина непосредно изнад површине воде“ (Sebestyén, 1908: 57). Ове две греде служиле су за подизање воденичног точка/кола 22 након заустављања рада воденице. За другу греду и гвоздену узенгију нисмо добили називе ни од једног казивача. Један крај попречне греде на којој је фиксиран воденични точак био је рачвастог облика, двокрак, одакле и назив ра́сова (,рачва“).

18. Назив направе за подешавање размака између горњег и доњег камена није био познат казивачицама [* Не́ знамо, то́ је како́ се cnýuћ'a!; то́ је ова́ко би́ло - да су́ч'еш, то́ је пак би́ло не̣́што у желе́зу ... не́ знамо како́ се вели́ то́!], али смо добили назив током друге анкете: [*] дига́ч'(?), има́л филе́m.

19. Гвоздена оса која спаја воденично коло са првим, већим точком [ве́лика ка́рика, по вели́ка ка́рика] који се налази унутар воденице назива се: [*] врте́́љка и врете́но; [*] óc /vreteno*, os*/ (уп. вp/el тёно, вртӥло $\rightarrow$ Букумирић, 2002: 161).

20. Гвоздена оса (шипка, стуб), која спаја мањи точак са горњим воденичним каменом и тако га окреће, зове се такође [*] врте̣́sка или óc, [*] óc, врете́но.

21. За назив за усправно постављен горњи гвоздени део вретена на којем лежи горњи камен у виду крста добили смо одговор само од једног казивача [*] nṕsneљиųa /prepelica*/.

\footnotetext{
${ }^{21}$ Дрвени точак какав је био почетком прошлог века замењен је касније (негде средином века, вероватно) железним точком и перајима.

${ }^{22}$ Изгледа да су у ту сврху коришћене у прошлости, не и у последњим деценијама (према казивању П. Калине).
} 
22. Казивачима је непознат назив за трупчић у доњем камену кроз који пролази осовина.

23. Један од два камена круга који мељу жито зове се ка́мен, ка́мен водени́ч'ни /vodenični kamen*/.

24. Камени круг који се окреће зове се го́рњи ка́мен, а камени круг (доњи) који је непокретан зове се до́лњи ка́мен.

25. Дрвена направа обложена лимом, оклоп у виду круга који опасује камење и спречава да се оно што се меље не расипа свуда унаоколо зове се [*] околи́ш; [*] - /mašnici*/.

26. Отвор на горњем камену кроз који пада зрневље назива се [*] ду́пка [?] (,,рупа, отвор“).

27. Кроз цевчицу причвршћену на дну коша зрневље пада у мали претинац звани [*] каба́л.

28. За греде које служе као лежиште за доњи камен каже се [*] постаме́нт.

29. Скоро половину просторије у унутрашњости млина чини постоље од брвана, узвишено око 50 цм, на којем је смештено воденично камење и кош, а које носи назив nóm $^{\partial}$.

30. Направа за пењање на́`пот

31. За сандук изнад воденичног камена у који се сипа кукуруз (ређе жито или овас) забележена је лексема ко́ш /koš*/.

32. Сандук поред воденичног камена у који пада брашно назива се ла́duйа [ла́дицуа (om дре̣́ва) за бра́шно] /korito*/.

33. Дрвена кашика којом се купило и сипало брашно у врећу зове се [*] лопа́ч’uц̧а [лопа́ч ’uй с ко́јом се мета́ло бра́шно у вре̣́ћ’y].

34. Мало корито испод сандука у који се сипа житарица која се меље, према тврдњама наших казивача, не постоји у карашевској воденици.

35. Забележили смо два назива за дрвце које удара по воденичном камену док се кукуруз меље: [*] тре́скалий $[\sigma]$ и [*] тете́рес (je фикси́ран за ко́ш) /teterez*/.

36. Нисмо успели сазнати назив за примитивну справу која служи за подешавање количине кукуруза (Н: кукýрyu, Г: кукурýsa / [?] kukuruz*/), жита (жúmo), овса (о́вас)/ који пада из коша на воденични камен да се меље ${ }^{23}$.

37. Кратка цевчица фиксирана на дну коша кроз коју пада зрневље кукуруза у каблић смештен изнад горњег воденичног камена зове ce [*] ду́duи̧a.

38. Направа на дну коша са које пада зрневље из коша у каблић смештен на горњем воденичном камену зове се [**] вало́в ${ }^{\phi}$, (дем.) вало́вак [вало́вак је би́л над ${ }^{m}$ ка́блам].

\footnotetext{
${ }^{23}$ Убеђени смо да постоји назив али га се казивачище нису могле сетити.
} 
39. Нисмо добили одговор за направу (која сигурно постоји и у карашевској воденици) за најављивање недостатка зрневља у кошу.

40. На питање како се зове статична направа за мерење тежине житарица донете да се самеље (вага) одговор је био: [*] Hé ce ме́рило. Ми́ не́смо има́ли канта́р у водени́uฺи, Ми́љо!. Истом лексемом - канта́p - означава се и направа за мерење тежине која се састоји од полуге са поддеоницама, покретне кугле, две куке (кýке) и таса (maњи́p) окаченог на три ланца (ла́нч'úћ'u).

41. За лексему „тег“, различите величине и утврђене тежине, који се ставља на тас ваге при мерењу тежине, употребљавају се две лексеме греутаћ'e и кила́uи.

42. Лексемом бо́ma именује се покретна кугла на кантару.

43. Будући да у воденицама није било справа за тачно мерење тежине (вага или кантар), житарице оних који нису сувласници мерене су дрвеном посудом званом /kepec*/ (у прошлости), а данас се користи само лексема ме́pa /merica*/. Има више различитих таквих посуда за мерење: ли́тра, полова́к који има де́сет ли́тре (=cе́дам и́по ки́ле / 7,5 кг) (дем: полова́кч'uћ'), ме́тер који и́ма дваде́сет ли́тре (= петна́јст ки́ле / 15 кг).

44. Шта се млело (које житарице) у воденицама у Карашеву? - Жи́то и куку́руц..., дру́го се не̣ мле́ло ... о́вас ... ко́ј што има́л ... мле́ло се за ма́ру најви́ше, али се ч'ини́ла и ч'ṕна пúma (,хлеб“) ..., куку́руи за ма́ндру („проја, качамак, палента“), то́ се мле́ло.

45. Прах од самлевеног кукуруза (жита, овса) зове се бра́шно /brasno*/. 46. Назив за љушчице од самлевеног жита које се при млевењу одвајају од брашна: три́ųе.

47. Како се зове брашно:

а) од кукуруза: кукуру́жно бра́шно / бра́шно кукуру́жно;

б) од жита (пшенице): иини́ч'но бра́шно / бра́шно шини́ч'но;

в) од овса: бра́шно от о́вса;

г) од јечма: [*] бра́шно от јеч'ме́на.

48. Крупно самлевен кукуруз што се меље за исхрану стоке назива се [*] o pýj, [*] opýj, $o^{y} p y ́ j$.

49. У вези са крупноћом брашна, воденица може да меље:

а) крупно (на крупно): [*] бо́басто;

б) ситно (на ситно): [*] дро́бно.

50. Џак од тканине у којем се доноси у воденицу кукуруз (ређе, жито или овас) и потом се кући односи брашно назива се вре̣ћ'a [вре̣ћ'a тка́на на разбójy] /brasnena vreća*/ и ме́j (Н. мн: ме́јове) „мех“/mej*/.

51. Зависно од материјала од којег је израђен и/или запремине, за џак се користе још следећи називи: 
a) џак од материјала тканог на разбоју или од неког другог платна: ве́лика вре́ћ'a, вре̣́ћ'a по́ вели́ка; вре̣́ћ'ка (дем.) „врећица, мала врећа";

б) џак од телеће коже: ме̣j „мех“ (ме̣ј от ко́же от те́лаи, ме̣ј от ко́же от теле́та), ме̣́ч'ић' от ....(дем.);

в) џак од овчије коже: ме̣j от ко́же от о́вач;

г) џак од козје коже: - (не́смо /има́ли/, ч'e /jep/ ми́ не̣́смо има́ли ко́зе).

52. Алатка која је употребљавана да се врећа максимално напуни назива се [*] бата́ч' [се зби́ва бра́шно да ста́не у вре̣́ћ'y или у ме̣j] или [*] побијáч'/batač*/. Према Шебешћину, бата́ч' јесте алатка од врбовог дрвета дуга око 1,5 м (Sebestyén, 1908: 50).

53. Алатка којом се мете брашно у сандуку за брашно назива се [*] перу́шка [перу́шка от кри́ла от гу́ске].

54. Количина брашна која се узима као надокнада за млевење онима који нису сувласници воденице зове се [*] yjýм, [*] ojýм.

55. Забележили смо две лексеме којима се именује особа која ради у воденици, која меље кукуруз, наиме, за особу мушког пола назив је воденич'áp и помеља́p, а за особу женског пола - воденича́рка и помеља́рка.

56. За посао који обавља воденичар каже се да је то воденич'ápски поса́л.

57. Пошто карашевске воденице нису имале само једног већ више га́зде („власника“), они се зову [*] орта́u̧и [Орта́u̧и, орта́u̧и Ми́љьо! Сви́ смо дава́ли ко́ту ${ }^{24}$ и сви́ смо контрибу'і́тали с но́вцам и ра́ђ'ом!], [*] о́ртак, орта́ųu.

58. Чекић за посецање, оштрење камена нема посебан назив: [*] ч 'е̣кан, ч’ика́ни, су би́ли от оце́ла.

59. На питање да ли је неко од, ортака“ био главни, важнији од осталих, добили смо следећи одговор: [*] Не́, (али) је́ни су има́ли иॄе́л да́н (право да мељу), је́ни по́лак дан, и ти́ (неко ко није сувласник) кад до́ђ'еш он (онда) ти́ у́змемо ту ују́м; [*] Орта́ųu су има́ли по́лак да́н, је́дан, два́ или ч’ак три́ да́на.

60. На питање како и када су могли млети они Карашевци који нису били сувласници, одговорено нам је да су дотични могли млети онда кад им неко од орта́ка уступи свој (део) дан(а). Углавном, већина мештана била су сувласници у некој од постојећих воденица (Су би́ли по дваде́сет-триде́сет орта́ка... триз два́ у стра́жюе вре́мм /у Великој водениц̧и - наша примедба/).

\footnotetext{
${ }^{24}$ Казивачица Марија Ардељан овде говори о износу (доприносу) у производима који су сељаци у време комунистичког режима педесетих и шездесетих година прошлог века били приморани да дају држави.
} 


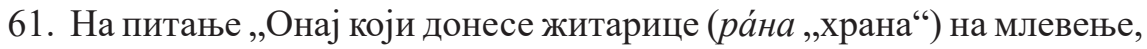
а није био међу ортацима (сувласник), оставља ли ту џак док се не самеље па се потом враћа по брашно или чека док се не самеље?“" - добијени су одговори: [*] Ма́не mý, mý мáне... кат ${ }^{\underline{\partial}}$ сти́гне на ре́m... На при́мер, де́сет вре̣ћ'e, (je) десе́ти кат сти́гне y водени́иу; го́ри („горе“) је́ст пóm , про́ти ко́ша (ту стави врећу); [*] че̣́ка на ре́ду.

62. Онда када се нешто поквари на воденици, сви сувласници учествовали су, физички или новцем, да се квар отклони: [*] cви́ контрибу júmajy та́мо, да се ја́зи... сви́ ја́зе, или сви́ контрибујúтају но́вцам... и ч'ика́не (чекићање воденичног камења), и су ју завија́ли (покривали), купува́ли пле́к от циркве ${ }^{25} \ldots$ и ши́не ${ }^{26}$ ме́ћ'y... .

63. На питање да ли су запамтили/чули од старијих да у појединим годинама воденице нису извесно време радиле због суше, одговор је био потврдан: Па то́ ле́ти... не̣ и́шла ни́како. Не̣ и́шла ле̣ти кад не во́да!

64. Да ли је могла једна особа сама да пусти воденицу да ради и да меље или му је био потребан за то још неки, добијен је одговор: [*] Са́м си мо́гал... ди́гне ста́вило пр́во и по́си пу́шћ'аш водени́иу.... са́мо ко́ј не́ уме̣́л (... није могао).

65. На питање да ли се у неком годишњем добу више млело него у другом, одговор гласи: [*] Це́ло вре̣́ме, Ми́љо, цее́ло вре̣́ме! Сва́ки да́н, смо има́ли ма́ру! Кра́ве, о́вце, сви́ње...(јер је требало) за ма́ру и за на́c... .

66. На питање да ли је постојао неки утврђени редослед за млевење, добијен је следећи одговор: Не̣, ко́j ка́m има́л нево́љу да ме́ље. | У на́шој не́су, не́го ли та́мо су има́ли, у

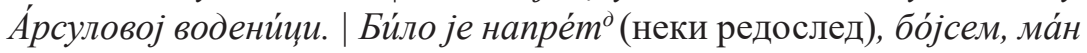
по́си не́ ви́mе.

67. Воденични кључ се налазио код једног од сувласника, обично

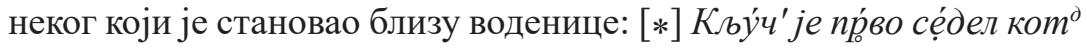
ба́бе Шћ'ефанко́ње (наше казивачице) у ста́ро до́бо, а по́cu кот Марја́на, поко́јног Стоја́на, де́ сам ја́ би́ла мла̄'dа. | Кот неєко́к по́ про́ти ре̣́ке, про́ти водени́це, ове́ј сока́к.

68. На питање да ли су воденице радиле само дању или и ноћу, одговор гласи: [*] Ка́ко да не́, и ноћ'óм, и при́дан, и у по́лноћ', најпа́ч'е ка́d не̣ во́да! Се ди́гнеш ку но́nћ'aн ка́n ${ }^{27}$, и на́веч'ер, и та́мо се ме́ље до

\footnotetext{
${ }^{25}$ Исказ казивачице се односи конкретно на случај када је купљен плех којим је била покривена црква и који је био замењен новим плехом.

${ }^{26}$ Шинама (гвозденим тракама) су негде педесетих година прошлога века почели замењивати иструлеле греде из основе грађевине (воденице) (в. сл. 2).
}

27 Румунска синтагма преузета мот-а-мот (са мало прилагођеним фонетизмом у духу 
пора́нини (,ујутро“) | Се ради́ло на ла́мпашу (,фењер“) !.

69. На питање да ли су и Карашевци из других карашевских насеља млели у Карашеву, добијени су не баш уверљиви одговори ${ }^{28}$ : [*] Кара́шевции са́мо, ја́ не̣ссам запа́мтила из дру́ги се́ли. Кад су доди́ли ми се... из Ја́балч'а па́мтим ч'е су доди́ли, а дру́ги не́_знам, им се узи́мал ују́м те́ј... У А́рсулову зна́м ч'е су доди́ли, а у ову́ не па́мтим, би́ћ'y доди́ли, ма́н не па́мтим! [Питање: А Нермиц'а́њьe?] Не́_знам за Нермий'́́ғве!

70. Према казивачима, Карашевци се нису окупљали у воденицама ради разговора и забаве [?].

71. На питање да ли Карашевци сматрају воденице опасним местима, односно да ли су чули приче о опасним, чудноватим бићима који се налазе у води и око воденица који нападају, утапају људе, одговор је био одричан [?] $]^{29}$.

72. На питање колико од постојећих воденица данас још ради, добијен је категорично одрични одговор: Није́на! Нúmu је́на! Све́ су се сурупата́ле, пропа́ле! Све́ су се сурупата́ле, ова́ ма́лко (Велика воденица) што́ је́ште ... (...није сасвим пропала).

73. Недељом и благданима није се млело: Не, тако́ не́смо по неде́љи, ни по светко́в! Ме́љемо и у субо́ту, ноћ'о́м, са́му у неде̣́љу не̣!

6. На основу коришћених упитника прикупљена грађа садржи укупно 126 лексема. Примењујући еимолошки критеријум, те воденичке термине и воденичарске лексеме ${ }^{30}$ коришћене у воденичарском занату сврстали смо у две велике групе (в. ниже - 6.1. и 6.2).

6.1. Термини и лексеме словенског порекла (92). У оквиру ове групе разликујемо две подгрупе, наиме:

6.1.1. Карашевски термини и лексеме (15):

бата́u', -ч'u $u^{31} /$ batač*/ „врбов штап дуг око 1,5 м” (<бámamu, бáћ'eм

карашевског говора) која значи „У праскозорје; У цик зоре“.

${ }^{28}$ То је тако јер већ шездесетак година, тачније - од када су се појавили мали кућни млинови, све ређе су из осталих насеља долазили да мељу у Карашеву.

${ }^{29}$ Мислимо да таква бића постоје и у карашевским веровањима, јер се сећам (М. Радан) да сам у детињству чуо бројне приче о таквим створењима, у овом случају реч је о водеґа́ку („водени дух који мами људе и утапа их у воду“).

30 Такве лексеме користе се и у другим доменима људске активности (в. нпр. лексеме бóma, о́блук, о́с и др).

31 у највећем броју случајева, лексеме добијене на постављена питања из упитника јесу најчешће у облику Н. једнине (ређе множине), па смо ми допунили додајући и онај други, множински облик (и обрнуто). 
„кљукати (живину); пунити, препунити“ [се зби́ва бра́шно да ста́не у вре̣́ћ'y или у ме́j] /син. побија́ч’; бо́ma, -me „покретна кугла на кантару; чобанска тојага, штап са заокругљеним горњим делом“ - вероватно је стара словенска лексема конзервисана у КГ (в. слов., пнслов. bŭtŭ; Skok, I: 194), али не искључујемо могућност да је позајмљеница из мађарског језика (мађ). bot <слов. bŭtŭ; уп. и рум. дијал. bótă, bóată <мађ. или из слов.); дигáч', -ч ’u „направа за подешавање размака између горњег и доњег камена“; дре́́во (дебе́ло ) (мн. др́ва) ,дрво“ - конзервисана архаична словенска лексема у КГ (стслов. drěvo); lobad*/,„ћерт, усек на греди брвнаре; горња и доња водоравна дрвена пречка на шарагама (коларски термин - в. Радан, Ускату, 2019)“, вероватно је стара конзервисана словенска лексема коју су позајмили и Румуни (уп. рум. obádă; према етимолошком речнику Чоранескуа, лексема је вероватно словенског порекла настала контаминацијом двеју лексема

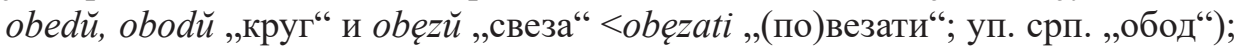
о́блук, мн. облу́йи „прозор“ (дем. обли́ч'ић', -ћ'u, ,прозорчић“) прасловенска конзервисана лексема коју су позајмили неки балкански народи (в. мађ. ablak, рум. дијал. oblóc); óc, ócoвe los*/ „ôc, осовина“ (слов. osǐ); peračna [?] / karika*/ „који се односни на пераје воденичног кола/точка“; побијáu’, -ч'u ,алатка која је употребљавана да се врећа максимално напуни“ (син: бата́ч’); пóm , подо́ве /nóдовеl „таван“ - стара конзервисана словенска лексема у КГ (<слов. родй, уп. рум. рód <слов.); пр́nељица (мн. пṕnељице ?) /prepelica*/ „чекетало; (фиг.) каже се за неког који стално брзо хода“ (можда је лексема у вези са глаголом п्р̈пати „чепркати“ ?); трна́ц, -ц̧и „трем“ / trnac*/ ,трем“ - према Скоку, лексема је или словенског или балканско латинског порекла (в. мађ. tornác и рум. târnáț); ч’ẹ́кан, мн. ч’uкáни „чекић“, словенска архаична лексема конзервисана у КГ (слов. с̌ekanŭ); $\boldsymbol{ч}$ 'ика́не (3. л. мн) „чекићање (воденичног камења)“.

\subsection{2. Термини и лексеме заједнички српском језичком ареалу (77):}

бо́басто (<бóба /<слов. bobŭ) ,,семенка; зрнасто вариво (пасуљ, грашак и сл); ситан округласт предмет уопште“); /brasnena vreća*/ (брашне́на); бра́шно /brasno*/; кукуру́жно бра́шно (бра́шно кукуру́жно); иини́ч'но бра́шно (бра́шно циини́ч'но) (<пшеница); бра́шно от о́вса; бр́вно, -на / brona*/; вало́в $^{\phi},-в и$ „валов, жљеб, олук“ (дем. вало́вак, -ки); водени́ца, -цее /vodenica*//миáлa / (дем. водени́ч'ка, -ке ,мала воденица; друштвена игра за коју се користи картон са специјалним цртежом на њему на којем играчи покрећу округласте предмете /најчешће семенке пасуља или кукуруза/ по извесним правилима“); воденич'áp, -ри; воденича́рка, -ке; водени́ч'ни (

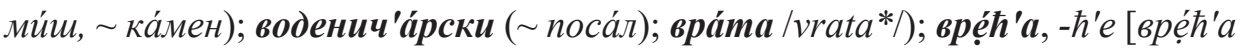
тка́на на разбо́jy] /brasnena vré́a*/, ве́лика вре̣ћ'a, вре̣ћ'a по́ вели́ка; (дем. вре̣́ћ'ка, -ке) „врећица, мала врећа“; врте́́,кка, -ке (уп. вртӥло $\rightarrow$ Букумирић, 2002: 161); врете́но, -на /vreteno*/(уп. вр/е/тёно $\rightarrow$ Букумирић, 2002: 161); гьи́ла, -ле „глина“; го́рњи ( ка́мен); гре́да, -де /greda*/; до́лњи ( ка́мен); 
(дро́бан, дро́бна) дро́бно „дробно, ситно“, конзервисана архаична словенска лексема (слов. drob̌); ду́nка, -ке,,рупа, отвор“; ду́дица, -и̧е дем. ( карич’ácma) (< $<y ́ d a$, „у́да, цев кроз коју се доводи или одводи вода или друга материја, у овом случају - семенке кукуруза, жита, јечма“); зи́m, зи́дове /zid*/; жсле́́зо, -за (конзервисани архаизам), „вожђе“; жжље̣n, мн. жље́бове /žljeb*/ [жље́n je

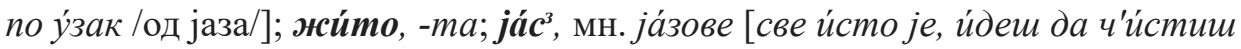
ја́с зли јару́zy, да ја́зимо]; смо јази́ли ,јазити“; јару́zа, -ге /jaruga*/; бра́шно от јеч'ме́на (Н. јд. је́ч'мен, мн. јеч'ме́ни) ,јечам, јечмен“; каба́л „кабао“, мн. кабло́ве; ка́мен (мн. каме́ње) (воденич'ни ) /vodenični kamen*/; кљу́и', кључ'е́ве; /korito*/ (кори́mo, -та) /ла́дица/; ко́ш, коше́ве /kоร̌*/ „воденични кош; оџак“; ку́ке (јд. ку́ка); ла́нч'ић'и (јд. ла́нч'uћ') дем. (<ла́наи); лопа́ч'ица, -иее дем. (<лопатка + -ица); /medvẹdica*/ дем. (<ме́двит /Н мн. медве̣ђ'еl „медвед“); ме̣j /mеј*/ (Н. мн: ме̣јове) „мех“ (ме̣ј от ко́же от те́лаи, от ко́же от о́ваи); ме̣́ч'ић', - ћ'u дем. ( om ...); се ме́ри(ло) „мерити“; ме́љем „млети“; ме̣́pa, -ре /merica*/; /merica*/ дем. (<ме̣ра); ми́ш, -ии (водени́ч'ни 〜); о́бруч', -ч’u; о́вас (мн. ?); огњи́ште, -ma lognjište*/; околи́ш, -ии (син. / mašnici*/), „ӧколӣш, ограда око млинског камена, која спречава расипање брашна“; перу́шка, -ке [перу́шка от кри́ла от гу́ске] „пѐрушка“; по́кров, покро́ви ( у две́ во́де, y четúри во́де) /pokrov*/ „покров, кров“; пе́ра /pera*/ (јд. пе́ро) „издубљене дашчице на воденичном колу/точку у које удара вода“; полова́к, -и̧и (=де́сет ли́тре = се́дам и́по ки́ле / 7,5 кг) (дем. полова́кч'ић') (уп. „Поло̀ва̄к“); помеља́р, -ри; помеља́рка, -ке; поса́л, посло́ве „посао“ (воденич'а́рски ); пра́к (пра́гове) /prag*/; páна (пл. тант.), храна, житарице и др.“; ра́сова, -ве /rasova*/ „рачва, расохе“; реме́н, -юе „каиш, ремен“; / sloga*/ (в. горе 5.17); со́бица, -ц̧е (дем.); се сnýuћ'a, сппуштати“; ста́вило, -ла /stavilo*/ „направа за спречавање течења воде кроз жљеб“ (<зауставити,

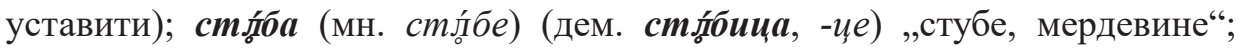
су́ч'еш „сукати, завијати“; тре́скалица, -цее /син: тете́рес/ „чекетало“; три́це (пл. тант.) „трица“ (<слов. trice); yjýм /фон. лик: ojýм/ (мн. уjýмu, ојýмu) ,ујам“ (уп. рум. uіúm < буг. ујем, срп. ујам) - словенска лексема која је у КГ, под утицајем румунског облика, претрпела фонетску промену лика; /сер */, „шиљати комад гвожђа усађен у средину главине који улази у бро́нзу (bronca*); грана (дрвета); божићна јелка“.

6.2. Позајмљени термини и лексеме (34). У овој групи имамо позајмљене термине и лексеме, непосредно или посредно, из неколико језика, наиме из:

\subsection{1. Румунског језика (13):}

sреутаћ'a, -ћ'e ,јединица за мерење тежине, тег“" (<рум. greutắti) / син. кила́m/; (смо) контрибу'и́тали, „допринети, учествовати““ (<рум. а contribui „исто”); ко́ma, -me „допринос који су сељаци били приморани давати држави у време комунистичког уређења“ (<рум. cótă „износ, део; допринос"“); мањиве́ла, -ле ,ручица, ручка“" (<рум. manivélă); ơpýj, -ju 
„прекрупа (за сточну употребу)“ - највероватније је позајмљеница из румунског језика (в. рум. ur/l/uiálă „исто“ <мађ). ӧrölni „крупно млевење житарица за прекупу“"); оце́л, -ли ,челик“" (<рум. oțel); постаме́нm, -ти „постамен(а)Т“ (<рум. postamént); cypynámaн, -на, -но - позајмљеница из румунског језика, в. и уп. a /se/ surpá ,пропасти, срушити /ce/, уништити, упропастити /ce/", в. и заст. варијанту a surupa (<лат. *subrūpāre)(DER: 763), уп. срп. сурвати; memépec /teterez*/ „чекетало; човек који много, стално говори, брбља“ (<рум. titiréz „чекетало /на воденици/; петица /на вретену/; чигра;“"); је фикси́ран „фиксирати, утврдити“ (<рум. a fixá „исто“); филе́m, -ти ,завртањ, спирални рез““ (<рум. filét „исто“); фундаме́нт, -ти /fundament*/ „фундамен(а)т, темељ“ (<рум. fundamént); kукýрyц (Н. мн. кукуру́su) „кукуруз“ (<рум. дијал. сисurúdz<мађ. kukorica).

\subsection{2. Немачког језика (9):}

бро́нза (фон. лик: бро́нз, бро́ни) /bronca*/, „метално лежиште причвршћено на попречној греди (ра́сови) у које улази врх воденичког вретена; бронза“" (<нем. Bronze, уп. рум. brónz); ками́на, -не /kamina*/ „камина, отворена пећ у зиду собе“ (<нем. Kamin <лат. <грч.); ла́дица, -и̧е „сандук; ладица“ (>нем. Lade) [ла́дuц̧а (om дре́ва) за бра́шно]; /mašnici* apx./ (син: околи́u), „дрвена или лимена ограда око млинског камена, која спречава расипање брашна“ (највероватније изведеница од лексеме „машна“ $<$ нем. Masche); ме́mep, -pu, метар, основна јединица за мерење дужине и (у овом случају) запремине житарица /úма дваде́сет ли́тре (= петна́jcm ки́ле

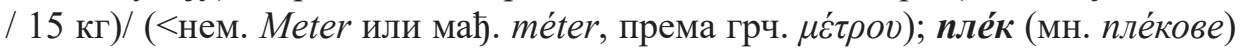
„плех, лим“ (<нем. Blech); ци́гла, -ле „цреп; опека“" (<нем. Ziegel; в. и рум. tiglă „цреп; опека“ < нем. или срп. „цигла“); шú на, -не „шина, дугачак комад профилираног челика који служи као носач“ (<нем. Schiene); ши́ндра, -дре „шиндра“" (<нем. Schindel).

\subsection{3. Мађ арског језика (5):}

гáзда, -де „човек који има велико имање или новац, богаташ; домаћин, глава породице, старешина“" (>мађ. gazda); ка́рuка, -ке /[?] peračna karika*/ „точак“ (<мађ. karika) [по вели́ка ка́рика]; ла́мпаш, -ии „фењер“ (<мађ.

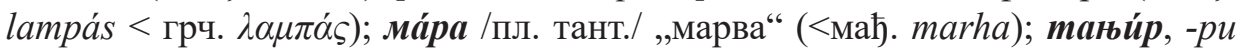
„тас на ваги; тањир“ (<мађ. tányér; в. и рум. бан. tăńér)

\subsection{4. Грчког језика (4):}

кила́ш, -ии ,јединица за мерење тежине, тег“ (<килограм <грч.) /син. греутаћ'a/; ли́mpa, -mpe „литар/литра; нарочити суд за мерење течности; старинска мера за тежину од око 320 г.“ (према срлат. litra, лат. libra <грч.

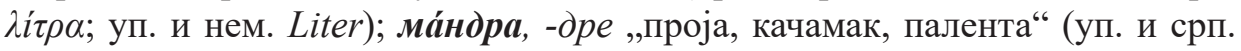
мӓндра и ма̂ндра) (<грч. mandra - према Скоку је балкански грецизам - Skok, II: 369; в. и тур. mandra); núma, -me (ч'ṕpнa ) „хлеб (црни )“ вероватно је балкански грецизам (сргрч. літ $\alpha$; в. и рум. дијал. pítă), али не 
искључујемо могућност да је слов. порекла (уп. рус. numámb, numámbcя „хранити, хранити се“").

\subsection{5. турског језика (3):}

канта́p, -ри „вага у облику металне шипке по којој се помера тег; вага, теразије (у опште)“ (<тур. kantar <ap.); /kepec*/, „посуда за мерење житарица“ - нејасна етимологија, можда је турцизам (в. срп. „кѐпчија, кѐвчија“ <тур. kepçe, kefçe <перс.; в. и уп. кёпе̄ц); о́ртак (мн. орта́u̧u) „сувласник (сувласници) воденице; ортак, сарадник или улагач капитала у заједничком послу, партнер“ (<тур. ortak).

6.3. За неколико од наведених позајмљеница није могуће прецизно утврдити из којег су језика позајмљене (предност је дата првом наведеном етимону), односно да ли су у КГ из неког језика ушле посредством другог језика, као у случају лексема ópýj, ме́тер, ла́мпаш, ма́ндра, пúma, кукýруu, можда и још понека.

\section{7. Закључне напомене}

7.1. Из горе изложеног описа стања воденичарства у Карашеву, неоспорно је да је оно изумрло пре неколико деценија. Иако је до спровођења анкете дошло са закашњењем, сматрамо да је истраживање ипак постигло основни зацртани циљ, наиме, да се спаси од заборава терминологија и лексика везана за воденичарство у Карашевака, бар већи део ње.

7.2. У односу на почетак прошлога века, уочене су поједине мање промене што се тиче грађевинског материјала, коришћеног једино при оправкама постојећих воденица (замена шиндре са лимом, делимична замена брвана са железним шинама и сл.), јер нове нису грађене. Уочена је, међутим, једна крупна иновација у погонском делу воденичног механизма. Наиме, почетком прошлог века воденично коло је директно било повезано са горњим воденичним каменом и окретало га је. Неколико деценија касније, међутим, ради повећања убрзања окретања воденичног камена, у механизам ће бити уграђена још два точка-ве́лика ка́рика, коју је покретало воденично коло са перајима, а ова је посредством реме́на (каиша) покретала мáлy ка́рикy, која је покретала горњи камен (в. нацрт 9).

7.3. Од укупно 126 лексема и термина, 92 словенског су порекла $(=\mathbf{7 3 , 0 1}$ \%). Од тих 92 лексеме и термина 15 су својствени КГ (16,30\%), а осталих 77 $(83,69$ \%) налазимо и у другим говорима са српског лингвистичког ареала. Такође. забележене су 34 позајмљенице, што од укупног броја забележених термина и лексема представља 26,98 \%. Према очекивањима, највише је 
румунских позајмљеница - 13 (38,23 \%), следе потом немачке - 9 (26,47 \%), мађарске - $5(13,51 \%)$, грчке - $4(10,81 \%)$ и турске $-3(8,10 \%)$.

7.4. Мештани Карашева и, уопште, сви Карашевци требали би под хитно консолидовати, рестаурирати и конзервисати ово значајно културно благо за потомство.

\section{Литература}

Букумирић, 2002: М. Букумирић, Из воденичарске лексике Горње Метохије. Приштина - Лепосавић: Гласник Баштина, св. 14, Институт за српску културу, стр. 159-174.

Милорадовић, 2013: С. Милорадовић, Вода и понешто од воде у српским дијалекатским речницима. Београд: Aquatica: књижевност, култура (ур. Мирјана Детелић и Лидија Делић), Балканолошки институт САНУ, стр. 11-32.

Муњић, 2017: J. Муњић, Воденище Шумадије / Watermills of Šumadija. Крагујевац: едиција Наслеђе, књига 2, Завод за заштиту споменика културе Крагујевац (84 стр).

Радан, 2015: М. Н. Радан, Фонетика и фонологија карашевских говора. Прилог проучавању српских говора у Румунији. Нови Сад: Филозофски факултет у Новом Саду • Институт за српски језик САНУ, Београд - Матица српска, Нови Сад.

Радан, Ускату, 2016: М. Н. Радан, М-Р. Ускату, Карашевска пастирска терминологија (са посебним освртом на страни утицај у њој). Нови Сад: Језици и културе у времену и простору, V, Тематски зборник, Универзитет у Новом Саду, Филозофски факултет Нови Сад, стр. 55-67.

Радан, 2017: М. Н. Радан, О пореклу карашевске ковачке терминологије у говорима Карашева и Клокотича. Темишвар / Ниш: Исходишта, 3, Савез Срба у Румунији • Universitatea de Vest din Timișoara • Филозофски факултет Универзитета у Нишу, еuv, стр. 329-344.

Радан, Ускату, 2018: М. Н. Радан, М-Р. Ускату, О кожухарској лексици и терминологији у српском говору Карашева. Нови Сад: Језици и културе у времену и простору, VII/1. Тематски зборник, Универзитет у Новом Саду, Филозофски факултет Нови Сад, стр. 41-53.

Радан, Ускату, 2019: М. Н. Радан, М-Р. Ускату; Неке позајмљенице у коларској терминологији говора Карашева. Београд: Наш језик, L / св. 2, Институт за српски језик САНУ, стр. 615-626.

Радовић, 1953: Б. Радовић, Воденице у Доњем Банату. Београд: Зборник Етнографског музеја Београд, стр. 78-85.

Тешић, 1998а: М. Тешић, Основни текст упитника за воденичку терминологију. Београд: Српски језик, бр. 3/1-2, година III, стр. 529-534.

Тешић,1998б: М. Тешић, Из воденичке терминологије рачанског краја. Београд: Српски језик, бр. 3/1-2, година III, стр. 287-292. 
Финдрик, 1983: Ранко Финдрик, Увод у проучавање старих воденица. Београд: Саопштењ $а, \mathrm{XV}$, Републички завод за заштиту споменика културе - Београд, стр. 95-117.

L. Hadrovics, Ungarische elemente im Serbocroatischen. Budapest: AKADÉMIAÍ KIADÓ, 1985.

Sebestyén, 1908: Sebestyén Károly Cs, A Krassovánok Kanalas-malma. Budapest: A Magyar Nemzeti Múzeum Néprajzi Osztályának Értesitöje. Az "Etnographia” Melléklete, стр. 50-59.

Sencu, 1983: V. Sencu, Plaiuri din Banat-Caraș-Severin - . București: Editura Sport - Turism.

Țeicu, 2012: D. Țeicu, Moara de apă din Banat. Presa universitară clujeană.

http://enciclopediaromaniei.ro/wiki/StEG

\section{Речници}

И. Клајн, М. Шипка, Велики речник страних речи и израза. Треће допуњено и исправљено издање. [Нови Сад]: Прометеј, 2008

Речник српскохрватског књижевног и народног језика. Том 1-20. Београд: Српска академија наука и уметности - Институт за српски (српскохрватски) језик, 1959-2017.

Речник српскохрватског књижевног језика. Књ. 1-6. Нови Сад (• Загреб): Матица српска (• Матица хрватска), 1967-1976.

DER: Al. Ciorănescu, Dicționarul etimologic al limbii române. București: Editura SAECULUM I. O., 2007.

Dicționarul explicativ al limbii române. [București]: Academia Republicii Socialiste România, Institutul de lingvistică din București, Editura Academiei Republicii Socialiste România, 1975.

Skok, I-IV: P. Skok, Etimologijski rječnik hrvatskoga ili srpskoga jezika, knj, I - 1971, knj. II - 1972, knj. II - 1973, knj. IV - 1974. Zagreb: Jugoslavenska akademija znanosti i umjetnosti.

A. Škaljić, Turcizmi u srpskohrvatskom jeziku (̌́esto izdanje). Sarajevo: «Svjetlost» Sarajevo, 1989.

\section{Дијакритчки знаци}

[ ] Унутар угластих заграда даје се шири одговор, са коментарима, објашњењима и слично, на карашевском говору (говорима).

[?] Стављен иза одговора означава да испитивач сумња у тачност одговора.

[^] Стављен иза питања означава мишљење испитивача да казивач/и/ нису разумели питање, а то је узрок одсуства или погрешног одговора.

[б] Стављен испред једног одговора показује да је термин сугерисао испитивач. 


\section{Поједини знаци коришћени у транскрипцији одговора казивача ${ }^{32}$}

$e^{\prime}=$ затворено $e$ (под акцентом)

$e=$ затворено $e$ (неакцентовано)

$\ddot{p}=$ вокално $p$ (под акцентом)

$p=$ вокално $p$ (неакцентовано)

Л́ $=$ вокално $л$ (под акцентом)
Л $=$ вокално л (неакцентовано) $u^{\prime}, \mu^{\prime}, \hbar^{\prime}, \hbar^{\prime}=$ африкати са мекшим изговором од истих у књижевном језику

\section{Скраћенище}

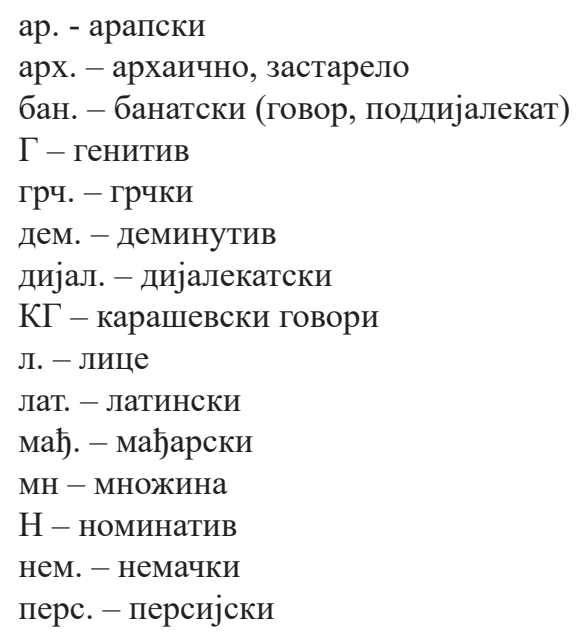

\section{Списак главних казивача}

Мари́ја До́бра (надимак: Шћ'ерфањко́ња), рођ. 1946, Карашево, бр. 225.

Мари́ја Ардељан ( - ), рођ. 1955, Карашево, бр. 239.

Ста́на Крста (Заро́њка) /девојачко име: Ћ'и́нкул, надимак: Миклошо́ња/, рођ. 11.

Х. 1946, Карашево, бр. 240 А.

Мари́ја Фи́лка (Ордаши́ца), рођена 1960, Карашево, бр. 240 Б.

Ма́рјан $^{33}$ /Пе́тар/ Кали́на, рођ. 05. 07. 1937, Карашево, бр. 216.

Сучајни казивачи:

Ми́ља Бо́шка (Го́ман), Равник, бр. 67.

Мари́јан Лукач'е́ла (Сви́рка), Клокотич, бр. 237.

Пе́тар Би́рта (Ми́кул), Клокотич, бр. 241.

Пе́тар У́рсул (Журке́ј), Јабалче, бр. 9.

\footnotetext{
32 Детаљније о овоме види код: Радан, 2015: 84-85.

${ }_{33}$ У званичним документима (крштеници) уписано је име Марјан, али га сви у селу знају и зову Пе́тар.
} 
Ми́ља Слове́нски (Дугали́ја), Карашево, бр. 98 А.

Мари́ја Ра́дан (Кумеса́рка) /дев. име: Ге́ра, надимак: Гай'́юа/, рођ. 1962 , Карашево, бр. 492.

\title{
TERMINOLOGIE DES MOULINS À EAU ET LEXIQUE DE LA MEUNERIE DANS LE DIALECTE SERBE DE CARAŞOVA
}

\begin{abstract}
Résumé
Cet ouvrage fait partie d'une série d'ouvrages des auteurs qui visent à enquêter sur ces sphères d'activités rurales des habitants de Caraşova, plus précisément, ces professions et métiers qui, dans les conditions d'une mondialisation de plus en plus accélérée, sont menacés d'extinction ou ont déjà disparu. Dans la partie introductive du document, il y a quelques clarifications sur l'enquête sur le terrain et les informateurs, sur les moulins et la meunerie à Carașova, la plus grande localité de Caraşoveni, indiquant également que l'objectif principal de cette recherche est d'inventorier les termes et le lexique liés à la meunerie, contribuant ainsi à leur préservation et à leur sauvetage de l'extinction.

Le contenu proprement dit de l'article consiste en la présentation du matériel collecté et son analyse afin d'indiquer l'origine de la terminologie et du lexique dans ce domaine de l'activité carasovienne et de voir dans quelle mesure d'autres langues ont influencé ce segment du. lexique carasovien.
\end{abstract}

Mots-clés: Carasova, moulins à eau, terminologie et lexique de la meunerie. 


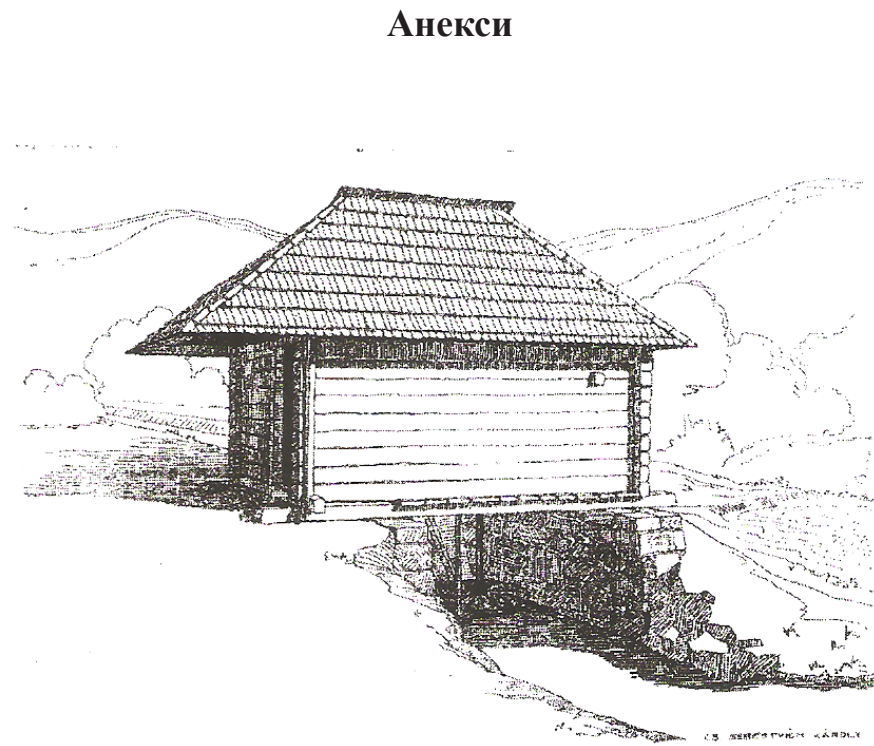

Сл. 1. Ве́лика водени́иа. Цртеж из 1908 (према Sebestyen, 1908: 51)

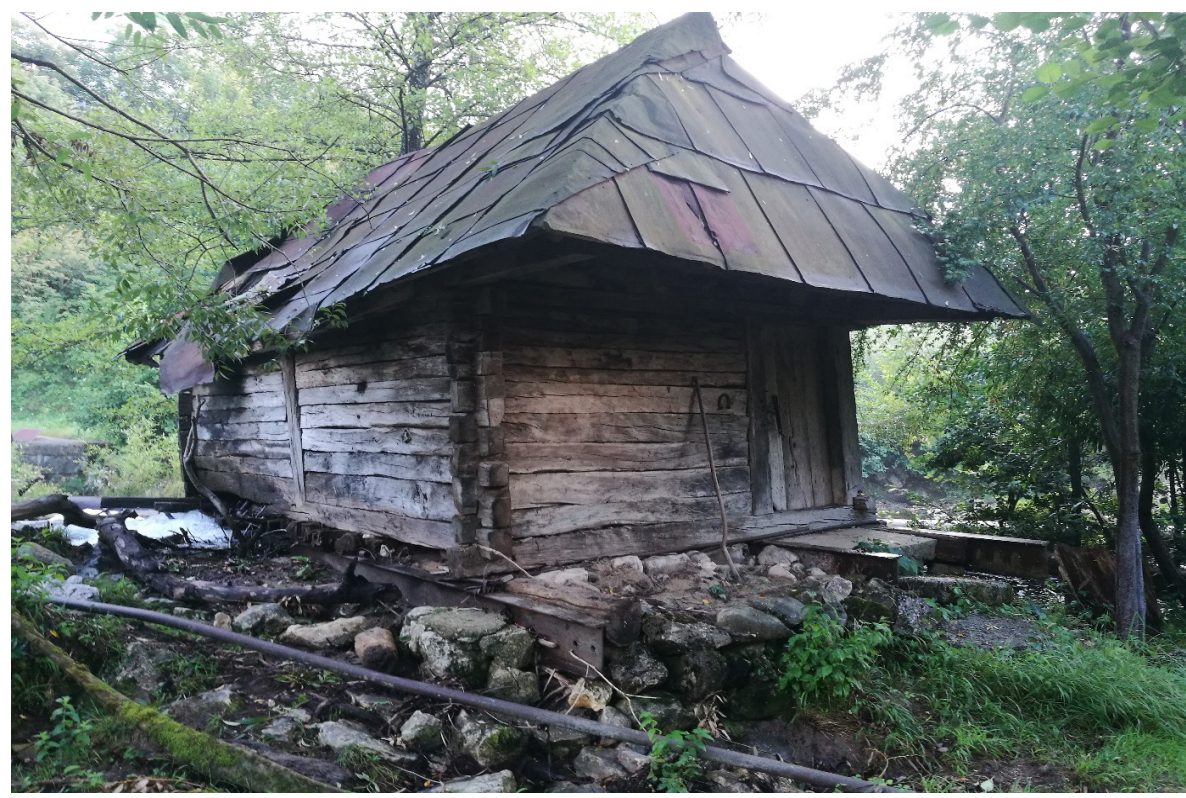

Сл. 2. Ве́лика водени́й (Једина од двеју воденица која се још није срушила, на месту званом Кот три́ водени́ие) -2020. 


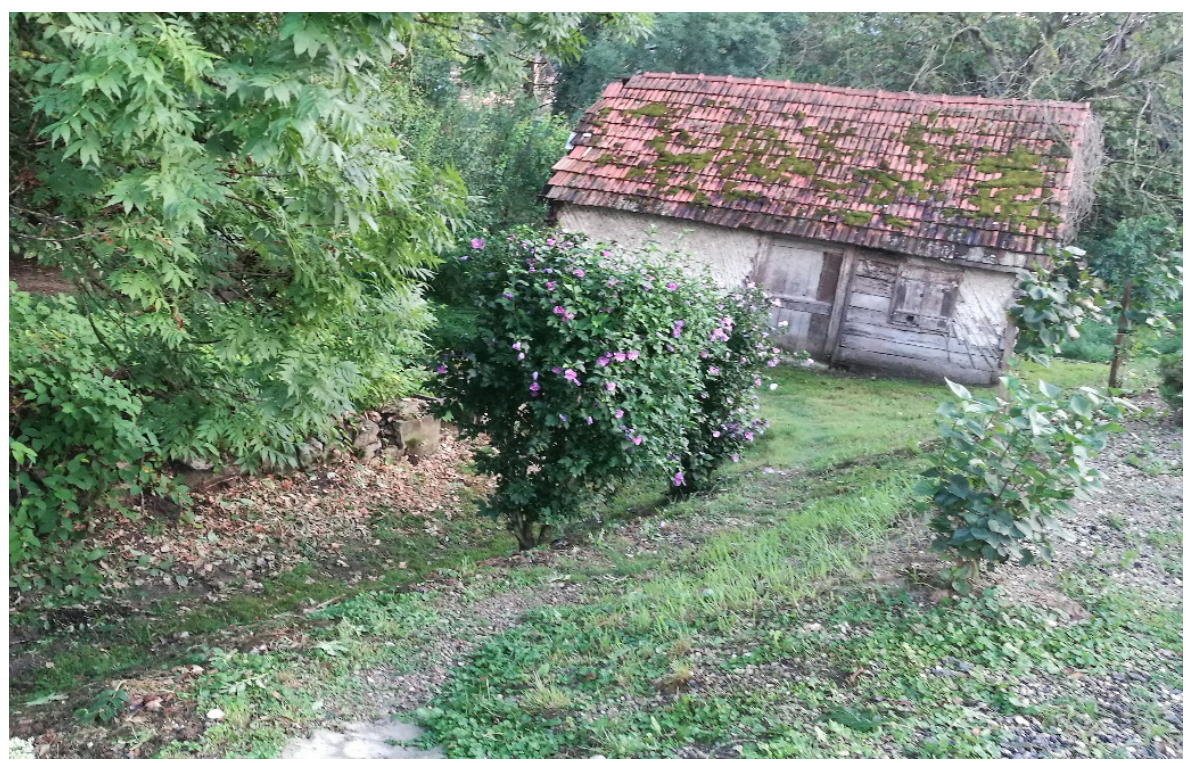

Сл. 3. Ге́рина водени́ųа (На Ве́ликим сока́ку)

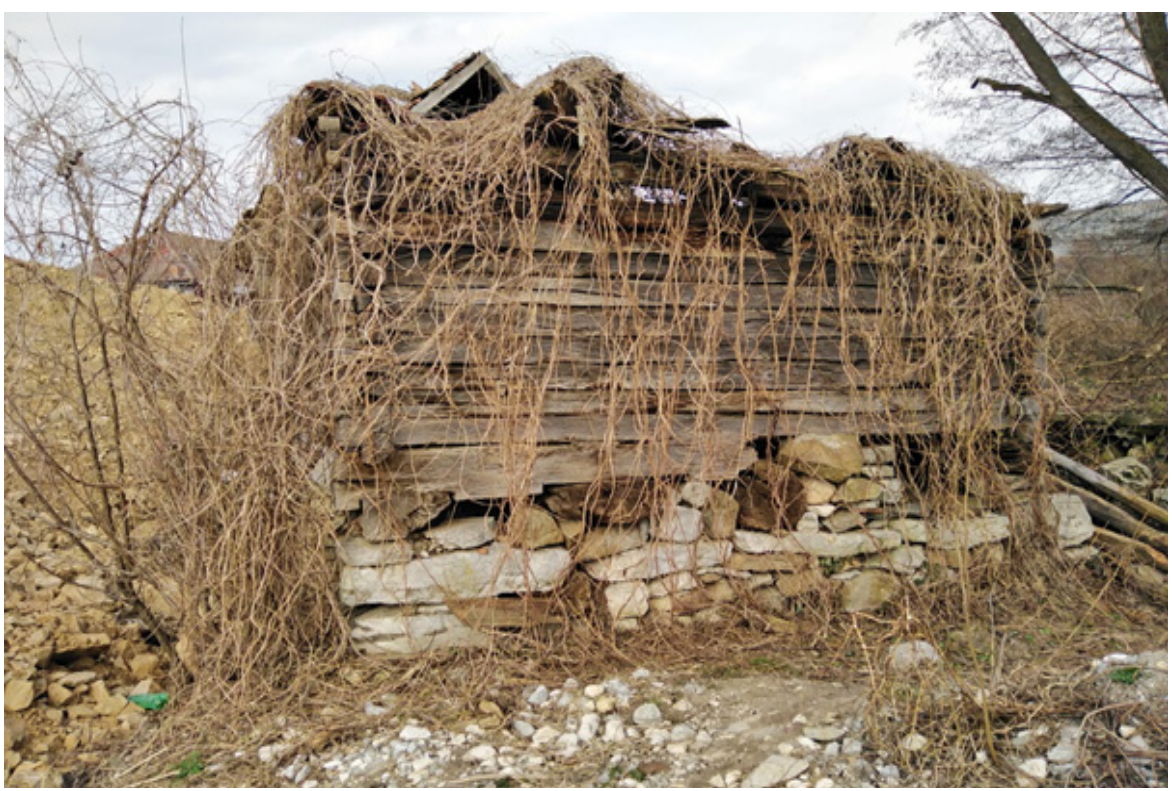

Сл. 4. Арсулова водени́ца (Арсуља́ч'a) 


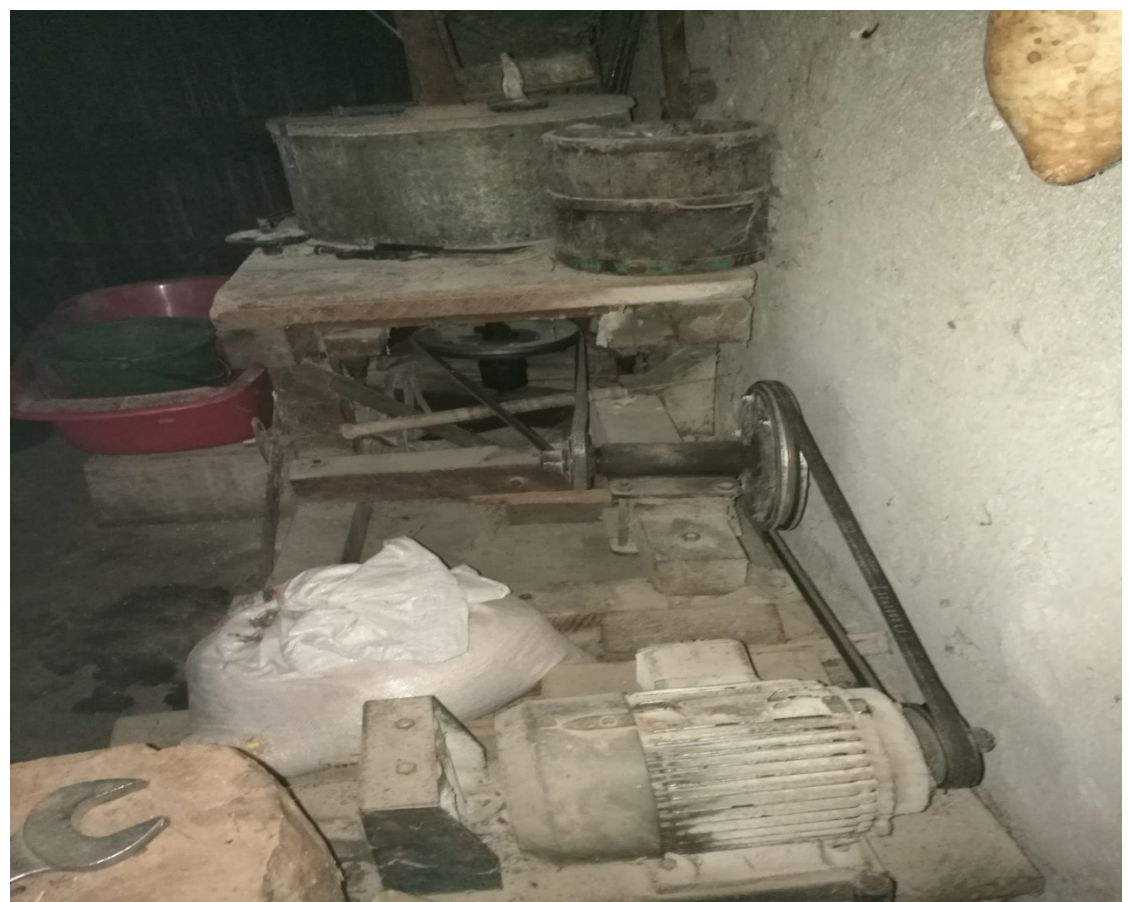

Сл. 5. Кућни млин на погон електромотора (Карашево, око 1975)

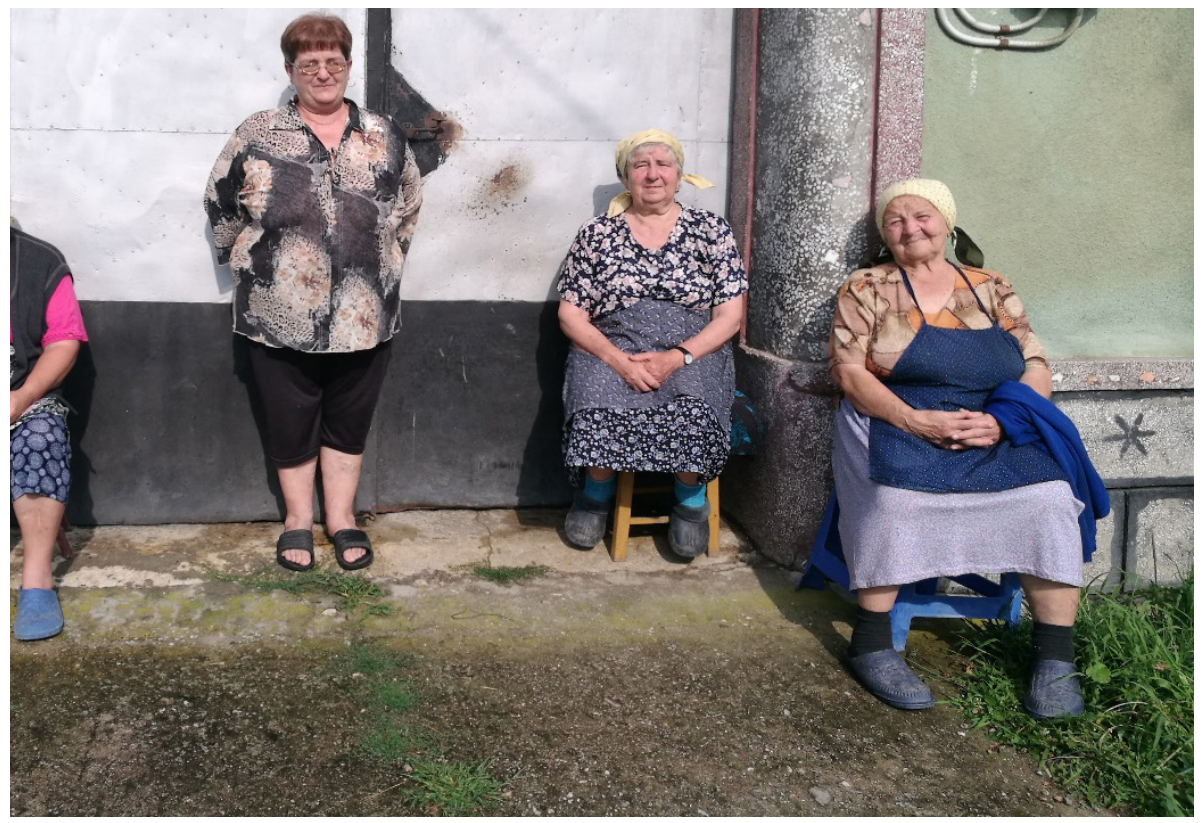

Сл. 6. Казивачи (с лева на десно: Марија Ардељан, Марија Филка, Стана Крста, Марија Добра) 


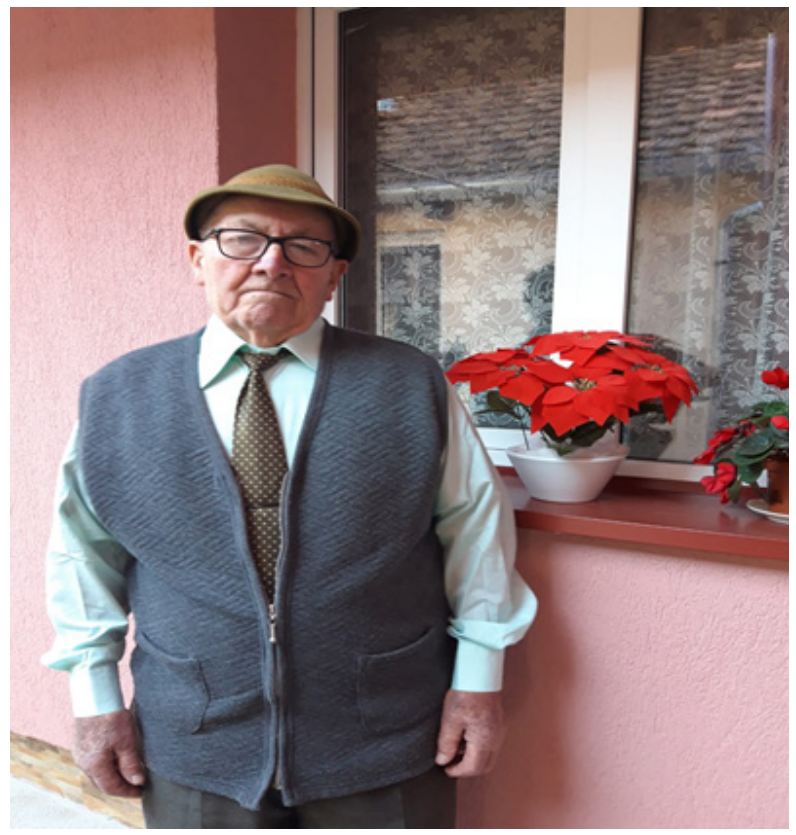

Сл. 7. Казивач Ма́рјан (Пе́тар) Кали́на

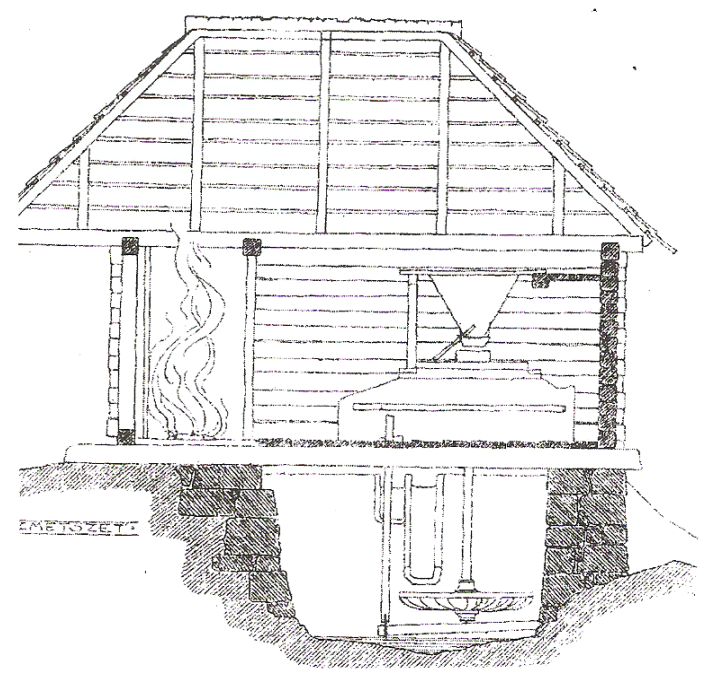

Нацрт 8. Попречни пресек млина из 1908 (Према Sebestyén, 1908: 54). 


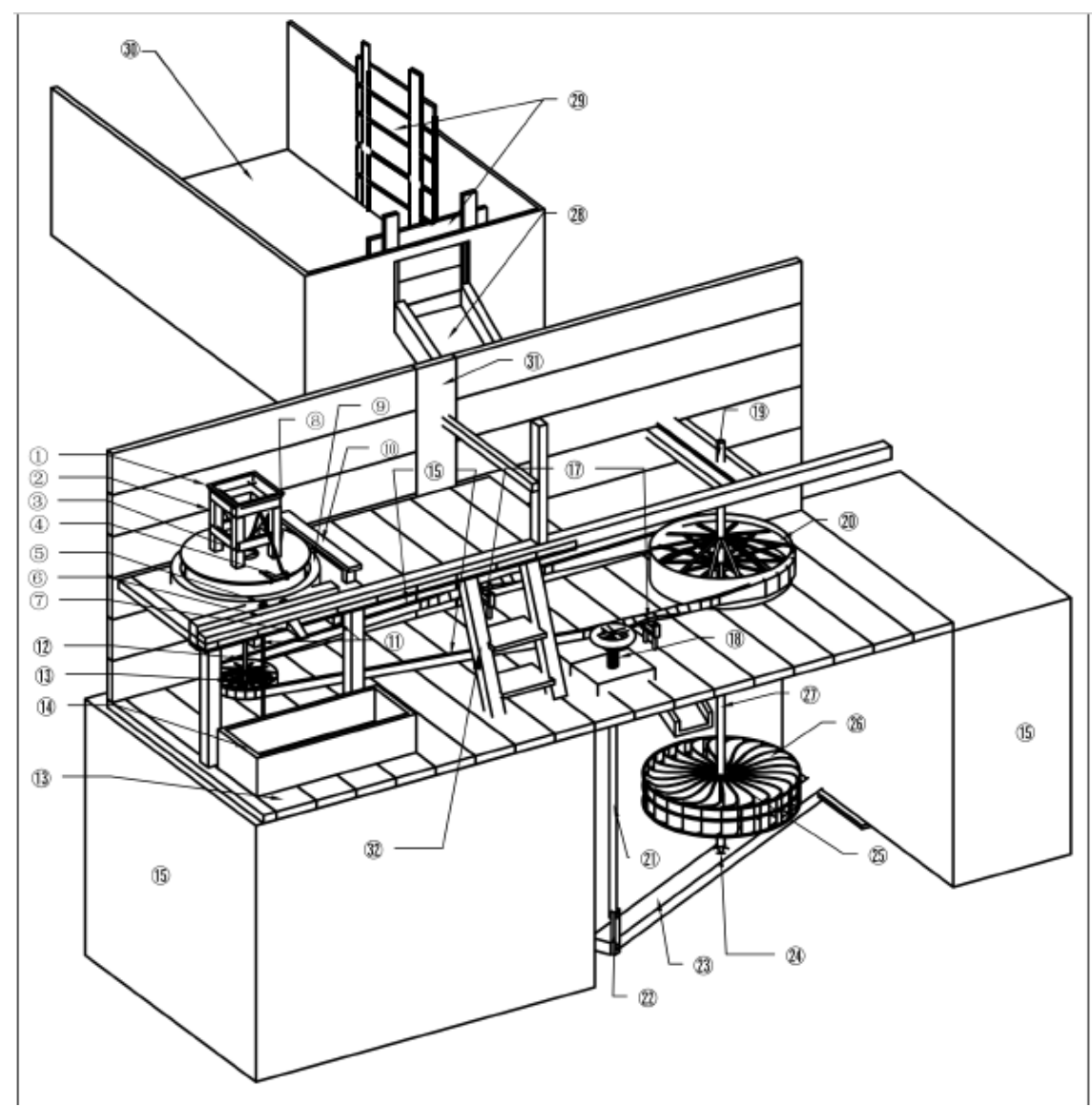

Нацрт 9. Функционална шема карашевског млина (2020. г).

1. Kóm

2. Стубови који држе кош (стл̊́nuи $)$

3. Дýdица

4. Тете́рес' тре́сккалиu

5. Околи́ш /mašnik*/

6. Постаме́нт

7. Отвор кроз који пролази брашно

8. Го́рњи ка́мен

9. До́льи ка́мен

10. /Klupa*/

11. Дига́ч'

12. Врте̣́љка, врете́но, óc/vreteno*, os*/
13. Ма́ла ка́рика (мали точак)

14. Лáduu̧a /korito*/

15. Реме́н (каиш) - Фундаме́нт / fundament*/, зúm / $z i d * /$ (темељ)

17. Потпора, супорт за каиш

18. Полуга за подиза-ње воденичног кола

19. Врте́лька, врете́но, óc/vreteno*, os*/

20. Ве́лика ка́рика (по вели́ка ка́рика)

21. /Medvẹdica*/
22. /Sloga*/

23. Ра́сова /rasova*/

24. Бро́нза/bronca*/

25. Ка́рика /peračna karika*/

26. Пе́pa /pera*/

27. Вроте́љка, врете́но, óc/vreteno*, os*/

28. Жљẹ́n /žljeb*/

29. Ста́вило /stavilo*/

30. jác , japýza /jaru$g a * /$

31. Гре́да /greda*/

32. Стก̆б(uи) $a$ 